\title{
Livros
}

\section{Doença: um estudo filosófico}

Leonidas Hegenberg. Rio de Janeiro: Editora Fiocruz, 1998. ISBN: 85-85676-44-2

A filosofia da medicina, atualmente, é valorizada em alguns países. Em vista disso, a abordagem do livro procura se aproximar, por meio de um pensamento crítico e argumentativo, do conceito, algo sem fronteiras nítidas, de doença.

Por que, o leitor pode perguntar, isso constituiria interesse fundamental para os psiquiatras? O médico tem a dimensão de um clínico (etimologicamente: aquele que vai ao leito), por assistir o enfermo, e uma dimensão não-clínica que o provê de conhecimentos cientificamente embasados a partir de um foco centrado sobre a doença, ou nos mecanismos íntimos que a engendram, e não sobre o doente.

Se a expectativa de uma pessoa enferma é a de que os médicos aliviem seu sofrimento (no inglês, distress), muitas vezes, apesar do indivíduo não apresentar necessariamente uma doença (disease), os médicos não podem esquivar-se do chamado dessa expectativa.

Acerca do último exposto, a psiquiatria se encaixa perfeitamente por vários motivos:

- primeiro, pelo caráter corretivo que ela pode ter relativamente às condutas que possam ferir a moral ou ideário vigentes no grupamento social em que está inserida, crítica erigida por Foucault e fonte de inspiração para Basaglia e todos os movimentos antipsiquiátricos e antinstituicionalistas posteriores. Sob esse prisma, a expectativa da sociedade é que os médicos tratem aquilo que lhe provoca sofrimento, estando ela doente ou não;

- a pessoa que sofre ou faz sofrer espera que o psiquiatra assuma a tarefa de aliviar seu sofrimento ou a responsabilidade por seus próprios atos, tarefa não acessível a quaisquer instrumentais propriamente terapêuticos, como a condição do enlutado, do paciente terminal, daquele que espera ansiosamente pela volta da mulher amada ou do que se ressente por haver cometido um crime passional. É bem claro que se pode ajudar pessoas como estas, mas essa tarefa não cabe necessariamente aos médicos. Também não se devem medicinar sofrimentos ou ações de natureza ontológica e/ou calcados no livre-arbítrio das pessoas;

- O terceiro motivo é o porquê de um psiquiatra mais positivista poder agir norteado pelo pressuposto de que tudo que causa sofrimento deva ser suprimido. Ora, como já houvera fundamentado William James, em As variedades da experiência religiosa, o sofrimento constitucional ou contextual - a crise - do ser humano não é, muitas vezes, o que o move para as conversões mais significativas, definitivas e bem-vindas de sua existência?

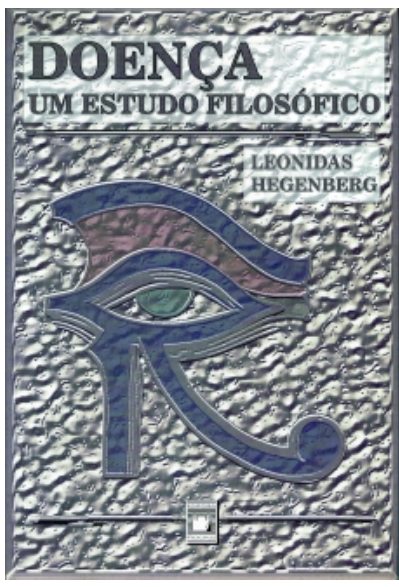

Enfim, a presente obra se junta ao clássico $O$ normal e o patológico, de Canguilhem, e traz luzes muito bem embasadas sobre o tema do conceito de doença.

Passa pela acepção de doença como "o não-desejável”, aquilo que se afasta da normalidade estatística ou aquilo que perdeu sua regulação homeostática, além de várias outras acepções, sempre com uma ótima e imparcial análise crítica.

A obra é recomendada, e finalizo com a lição de Prodi: "No clínico confluem, pois, duas realidades: a realidade das manifestações registráveis (os sintomas) e a realidade do seu quadro teórico. As suas capacidades para interferir na doença dependem de medida de habilidade idêntica para evidenciar o que existe (visível e instrumentalmente, direta e indiretamente) e da vastidão e precisão do quadro teórico de comparação que possui. As duas realidades alimentam-se reciprocamente, porque a capacidade de ver (...) é orientada pelo quadro teórico e, inversamente, a experiência não se pode acumular senão no interior deste. Por outro lado, o quadro teórico constrói-se, embora coletiva e quase impessoalmente, a partir de observações singulares. Porém, deve-se alimentar na formação do médico a aptidão (...) para a ligação entre o sintoma e o conjunto do código, e também para a flexibilidade com que o código muda sob a pressão dos novos conhecimentos científicos."

Mauro Aranha de Lima

Centro de Atenção Integrada à Saúde Mental (CAISM) da Irmandade da Santa Casa de Misericórdia de São Paulo 